\title{
Pengaruh Pengungkapan Other Comprehensive Income Terhadap Relevansi Nilai Informasi Akuntansi dengan Kualitas Audit sebagai Variabel Pemoderasi pada Perusahaan Industri Barang Konsumsi yang Terdaftar di Bursa Efek Indonesia Periode 2015-2017
}

\author{
Via Novita Sari ${ }^{1}$, Firman Surya ${ }^{2}$, Irda Rosita ${ }^{3}$ \\ ${ }^{1}$ Jurusan Akuntansi, Politeknik Negeri Padang \\ Email: vianovitasari96@gmail.com
}

Email:firm4n2003@gmail.com

Email: irda.rosita@yahoo.com

\begin{abstract}
This study aims to examine the effect of other comprehensive income disclosure towards value relevance of accounting information with the audit quality as moderating variables. The data used in this study is the secondary data obtained from the financial statements of consumer goods industry companies listed on the Indonesia Stock Exchange for the period of 2015-2017. The sampling technique used by using purposive sampling and it obtained the sample of 34 consumer goods industry companies. The data analysis technique used is multiple linear regression analysis and dummy variable moderation test (subgroup) using SPSS version 20. The results showed that the disclosure of other comprehensive income do not affect the value relevance of accounting information which is moderated by audit quality.
\end{abstract}

Keywords: Disclosures of Other Comprehensive Income, Value Relevance of Accounting Information, Audit Quality.

\begin{abstract}
Abstrak
Penelitian ini bertujuan untuk menguji pengaruh pengungkapan other comprehensive income terhadap relevansi nilai informasi akuntansi dengan kualitas audit sebagai variabel pemoderasi. Data yang digunakan dalam penelitian ini adalah data sekunder yang diperoleh dari laporan keuangan perusahaan industri barang konsumsi yang terdaftar di Bursa Efek Indonesia periode 2015-2017. Teknik pengambilan sampel dilakukan dengan menggunakan purposive sampling dan diperoleh sampel sebanyak 34 perusahaan industri barang konsumsi. Teknis analisis data yang digunakan adalah analisis regresi linear berganda dan uji moderasi variabel dummy (sub-group) dengan menggunakan SPSS versi 20. Hasil penelitian menunjukkan bahwa pengungkapan other comprehensive income tidak berpengaruh terhadap relevansi nilai informasi akuntansi yang dimoderasi dengan kualitas audit.
\end{abstract}

Kata kunci: Pengungkapan Other Comprehensive Income, Relevansi Nilai Informasi Akuntansi, dan Kualitas Audit.

\section{Pendahuluan}

Laporan keuangan suatu perusahaan yang memiliki cabang di beberapa negara, membutuhkan satu standar akuntansi internasional yang dapat dimengerti oleh 
semua negara, tidak hanya di negara dimana laporan keuangan itu diterbitkan. Hal ini akan memudahkan para stakeholders di berbagai negara dalam memahami dan membandingkan laporan keuangan yang diterbitkan oleh perusahaan. Demi memenuhi kebutuhan perusahaan akan suatu standar akuntansi yang dapat digunakan secara internasional, International Accounting Standar Board (IASB) menyusun suatu standar akuntansi keuangan yang dinamakan International Financial Reporting Standar (IFRS).

Perubahan standar akuntansi yang telah diterapkan oleh suatu negara menjadi standar akuntansi internasional (IFRS) merupakan suatu hal yang tidak mudah untuk dilakukan dan memiliki berbagai tantangan. Negara pengadopsi harus mampu melakukan penyesuaian terhadap berbagai perbedaan karakteristik standar yang akan diadopsi, terutama jika perbedaan tersebut cukup signifikan. Salah satu karakteristik IFRS yang berbeda adalah adanya penggunaan konsep nilai wajar (fair value) yang sebelumnya menggunakan konsep biaya historis (historical cost). Sebagian kalangan menilai bahwa standar akuntansi dengan menggunakan konsep historical cost telah banyak kehilangan relevansinya karena kegagalannya mengukur realitas ekonomi. Akan tetapi, penggunaan konsep nilai wajar juga dinilai tidak mudah untuk diterapkan karena membutuhkan banyak estimasi, asumsi dan judgement dalam penggunaannya (Apandi, 2015).

Karakteristik IFRS lainnya yang berbeda dengan non IFRS yang timbul akibat adanya konsep nilai wajar adalah munculnya perkiraan penghasilan komprehensif lain (other comprehensive income). PSAK No. 1 (Revisi 2013) menyatakan bahwa penghasilan komprehensif lain berisi pos-pos penghasilan dan beban (termasuk penyesuaian reklasifikasi) yang tidak diakui dalam laba rugi sebagaimana disyaratkan atau diizinkan oleh Standar Akuntansi Keuangan (SAK). Berbagai penelitian mengenai relevansi nilai dari other comprehensive income (OCI) mulai banyak dilakukan dan memiliki hasil yang berbeda-beda.

Jika ditinjau lebih jauh, hasil penelitian yang berbeda-beda tersebut dapat disebabkan oleh reaksi pasar atas relevansi nilai dalam OCI yang ternyata ditanggapi berbeda antara satu investor dengan investor lainnya. Perbedaan reaksi pasar tersebut dapat disebabkan oleh kualitas informasi yang terkandung di dalam laporan keuangan yang telah diaudit oleh Kantor Akuntan Publik (KAP) karena komponen nilai OCI memiliki unsur subjektifitas yang tinggi disebabkan penggunaan estimasi, asumsi dan judgment dalam penyusunannya. Berdasarkan hal tersebut, diperlukan suatu proses audit berkualitas yang dilakukan oleh auditor. Auditor diwajibkan untuk melakukan evaluasi penggunaan estimasi, asumsi dan judgment yang dilakukan manajemen secara rasional serta menentukan konsistensi pengukuran dalam penggunaan konsep fair value. Kemampuan auditor untuk dapat menilai hal tersebut dengan baik akan mencerminkan kualitas audit dari auditor tersebut (Apandi, 2015). Semakin berkualitas audit yang dilakukan oleh auditor, maka berbagai pengungkapan yang terdapat dalam laporan keuangan perusahaan akan semakin dipercaya.

Berdasarkan penjelasan diatas dan berbagai penelitian yang telah dilakukan sebelumnya, penelitian mengenai pengungkapan other comprehensive income (OCI) terhadap relevansi nilai informasi akuntansi telah banyak dilakukan, akan tetapi penelitian yang menggunakan kualitas audit sebagai variabel moderator belum banyak dilakukan. Penelitian ini menggunakan sampel berupa perusahaan yang termasuk dalam sektor industri barang konsumsi di Bursa Efek Indonesia dikarenakan pesatnya peningkatan indeks sektor ini hingga akhir tahun 2017. 
Periode penelitian dimulai dari tahun 2015 hingga tahun 2017, dikarenakan pada tahun 2015 mulai diberlakukan peraturan yang mewajibkan perusahaan untuk melakukan pengungkapan dan penyajian other comprehensive income (OCI) berdasarkan PSAK 1 (Revisi 2013).

\section{Metode Penelitian}

\section{Variabel dependen}

Dalam penelitian ini yang menjadi variabel dependen adalah relevansi nilai informasi akuntansi yang diproksikan dengan harga saham. Harga saham diukur dengan log natural rata-rata harga saham $\mathrm{H}+3$ dan $\mathrm{H}-3$ setelah laporan keuangan auditan diterbitkan di Bursa Efek Indonesia, yang dirumuskan sebagai berikut:

$$
P \quad r i \quad c \quad e=L \quad n \quad H \quad a \quad r \quad g \quad a \quad S \text { a ha } m \frac{(H+3)+(H-3)}{2}
$$

\section{Variabel independen}

Variabel independen dalam penelitian ini adalah pengungkapan other comprehensive income (OCI) yang diukur dengan 6 indikator pengungkapan OCI berdasarkan PSAK 1 (Revisi 2013) sebagai berikut:

Tabel 1. Indikator Pengukuran OCl

\begin{tabular}{clc}
\hline No. & \multicolumn{1}{c}{ Indikator } & Skor \\
1 & $\begin{array}{l}\text { Terdapat bagian tersendiri yang menyajikan pos-pos OCl dalam } \\
\text { periode berjalan }\end{array}$ & 1 \\
2 & $\begin{array}{l}\mathrm{OCl} \text { diklasifikasikan berdasarkan sifat } \\
3\end{array}$ & $\begin{array}{l}\mathrm{OCl} \text { dikelompokkan ke dalam kelompok OCl yang akan di } \\
\text { reklasifikasi ke laba rugi atau tidak }\end{array}$ \\
4 & $\begin{array}{l}\text { Menyajikan OCl secara neto maupun sebelum dampak pajak } \\
\text { penghasilan terkait }\end{array}$ & 1 \\
5 & $\begin{array}{l}\text { Terdapat pajak penghasilan terkait masing-masing komponen OCl } \\
6\end{array}$ & 1 \\
\hline & \multicolumn{1}{c}{ Tidak terdapat pos-pos luar biasa } & 1 \\
\hline
\end{tabular}

Sumber: data diolah penulis dari PSAK 1 (Revisi 2013)

\section{Variabel moderator}

Variabel moderator pada penelitian ini adalah kualitas audit. Proksi yang digunakan untuk variabel ini adalah ukuran KAP. Pemilihan pengukuran ini berdasarkan hasil penelitian Lee dan Park (2013). Kualitas Audit (KAd) dalam penelitian ini diukur dengan menggunakan dummy variable. Apabila perusahaan menggunakan jasa audit KAP big four akan diberikan bobot 1 (satu), sedangkan jika perusahaan menggunakan jasa KAP non-big four akan diberikan bobot 0 (nol).

\section{Populasi}

Penelitian ini memiliki populasi berupa perusahaan-perusahaan sektor industri barang konsumsi yang terdaftar di BEI pada tahun 2015-2017. Periode 2015-2017 (3 tahun) digunakan sebagai periode pengamatan karena adanya perubahan standar akuntansi yang dinyatakan didalam PSAK 1 (Revisi 2013) mengenai kewajiban perusahaan menyajikan dan mengungkapan Other Comprehensive Income (OCI) 
dalam laporan laba rugi maupun terpisah serta dalam catatan atas laporan keuangan sesuai dengan indikator yang telah diatur dalam PSAK tersebut.

\section{Sampel}

Sampel dalam penelitian ini dipilih dengan metode purposive sampling, yaitu penentuan sampel berdasarkan kriteria tertentu sesuai dengan yang dikehendaki oleh peneliti. Adapun kriteria yang dipilih dalam penentuan sampel adalah sebagai berikut:

1. Perusahaan dalam sektor industri barang konsumsi yang menerbitkan laporan keuangan secara berturut-turut selama tahun 2015-2017.

2. Perusahaan dalam sektor industri barang konsumsi yang memiliki nilai other comprehensive income (OCI) tidak nol.

3. Perusahaan dalam sektor industri barang konsumsi yang menyediakan data keuangan sesuai dengan kebutuhan penelitian (data yang digunakan untuk menganalisis pengungkapan other comprehensive income, relevansi nilai informasi, dan kualitas audit).

Berdasarkan kriteria purposive sampling yang telah dijelaskan diatas, diperoleh sebanyak 34 perusahaan industri barang konsumsi yang memenuhi kriteria per tahunnya. Sehingga banyaknya data yang penulis gunakan dalam penelitian ini mulai dari tahun 2015 hingga 2017 adalah 102 perusahaan industri barang konsumsi.

\section{Metode analisis data}

Teknik analisis data yang digunakan dalam penelitian ini adalah regresi linier berganda dan uji moderasi variabel dummy (sub-group).

1) Regresi linier berganda

Dalam regresi linier berganda, terdapat tiga analisis data yang dilakukan, yaitu terdiri dari analisis statistik deskriptif, uji asumsi klasik, dan uji hipotesis. Analisis statistik deskriptif menggambarkan nilai minimum, maksimum, ratarata, dan standar deviasi dari masing-masing variabel yang penulis gunakan dalam penelitian ini. Selanjutnya uji asumsi klasik dan uji hipotesis. Uji hipotesis terdiri dari perhitungan koefisien determinan $\left(\mathrm{R}^{2}\right)$ untuk mengukur seberapa jauh kemampuan model dalam menerangkan variasi variabel dependen, uji secara simultan (uji F) dan uji secara parsial (uji t). Adapun persamaan regresi linier berganda dalam penelitian ini adalah sebagai berikut:

$$
\text { PRICE }=\alpha+\beta_{1} \mathrm{OCI}+\beta_{2} \mathrm{KAd}+\varepsilon
$$

Keterangan:

PRICE : Harga Saham

OCI : Other Comprehensive Income

KAd : Kualitas Audit

$\alpha$ : Konstanta 
$\beta_{1}, \beta_{2}$ : Koefisien Regresi

$\varepsilon$ : Standar error

2) Uji moderasi variabel dummy (sub-group)

Uji moderasi variabel dummy (sub-group) merupakan uji model persamaan regresi untuk menguji pengaruh variabel moderasi dengan membagi sampel menjadi dua sub-group atas dasar variabel ketiga yaitu variabel yang dihipotesiskan menjadi variabel moderasi. Setelah variabel moderasi dibagi menjadi dua sub-group, kemudian lakukan regresi dengan membentuk 3 model persamaan regresi sebagai berikut:

\section{Model Regresi 1:}

PRICE $=\alpha 1+\alpha 2$ OCI $+\varepsilon 1$ untuk total sampel KAP big four dan non big four

Model Regresi 2:

PRICE $=\beta 1+\beta 2$ OCI $+\varepsilon 2$ untuk total sampel KAP big four

Model Regresi 3:

PRICE $=\lambda 1+\lambda 2$ OCI $+\varepsilon 3$ untuk total sampel KAP non big four

Setelah melakukan regresi, akan diketahui restricted residual sum of squares atau RSSr untuk masing-masing regresi pada tabel ANOVA. Kemudian lakukan perhitungan dengan menggunakan uji chow sengan rumus sebagai berikut (Ghozali, 2013):

$$
\text { F hitung }=\frac{(\text { RSSr }- \text { RSSur }) / k}{(\text { RSSur }) /(n 1+n 2-2 k)}
$$

\section{Keterangan :}

RSSr : Restricted Residual Sum of Squares regresi model 1

RSSur : Restricted Residual Sum of Squares regresi model 2 ditambah model 3

$\mathrm{n} 1$ : Jumlah n model 2

n2: Jumlah n model 3

$\mathrm{k}$ : Jumlah sub-group

Kemudian bandingkan hasil $\mathrm{F}$ hitung dengan $\mathrm{F}$ tabel dengan ketentuan sebagai berikut:

a. Jika nilai $\mathrm{F}$ hitung < $\mathrm{F}$ Tabel, berarti tidak terdapat efek moderasi

b. Jika nilai F hitung > F Tabel, berarti terdapat efek moderasi

\section{Hasil dan Pembahasan}

Analisis statistik deskriptif 
Berikut ini adalah tabel analisis statistik deskriptif dari masing-masing variabel yang diuji:

Tabel 2. Statistik Deskriptif

\begin{tabular}{lccccc}
\hline & $\mathrm{N}$ & Minimum & Maximum & Mean & Std. Deviation \\
\hline PRICE & 102 & 4,6681 & 11,1872 & 7,257285 & 1,6404504 \\
OCl & 102 & 5 & 6 & 5,98 &, 139 \\
KAd & 102 & 0 & 1 &, 45 &, 500 \\
Valid N (listwise) & 102 & & & \\
\hline \multicolumn{7}{l}{ Sumber: Pengolahan data dengan SPSS 20 }
\end{tabular}

Tabel statistik deskriptif diatas menggambarkan nilai minimum, maksimum, mean (rata-rata) standar deviasi dari masing-masing variabel yang digunakan dalam penelitian ini.

\section{Hasil uji asumsi klasik}

Uji asumsi klasik yang digunakan dalam penelitian ini adalah uji normalitas, uji multikolinieritas, uji heteroskedastisitas dan uji autokorelasi.

1) Uji normalitas

Uji normalitas yang digunakan dalam penelitian ini adalah dengan melihat $P$ Plot Test, yaitu dengan melihat penyebaran titik dari sumbu diagonal garis normal. Berikut ini adalah hasil uji normalitas data dalam penelitian ini:

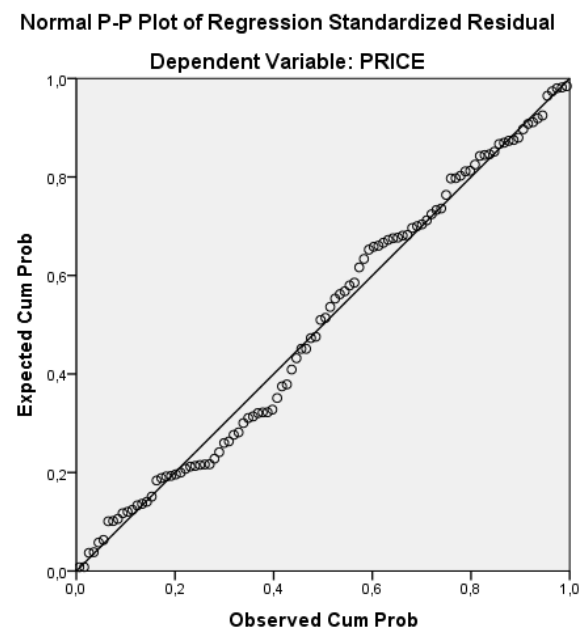

Gambar 1. Hasil Uji Normalitas

Sumber: Pengolahan data dengan SPSS 20

Berdasarkan grafik normalitas diatas terlihat bahwa titik-titik menyebar disekitar garis diagonal, seta penyebarannya mengikuti garis diagonal, sehingga dapat disimpulkan bahwa data berdistribusi normal.

Selain menggunakan P-Plot Test, penulis juga menggunakan uji One-Sample Kolmogorov-Smirnov Test untuk memperkuat hasil uji normalitas ini. Berikut ini adalah hasil dari uji One-Sample Kolmogorov-Smirnov Test: 
Tabel 3. Hasil Uji One-Sample Kolomogorov-Smirnov Test

\begin{tabular}{llr}
\hline & & $\begin{array}{c}\text { Unstandardized } \\
\text { Residual }\end{array}$ \\
\hline $\mathrm{N}$ & Mean & 102 \\
Normal Parameters ${ }^{\mathrm{a}, \mathrm{b}}$ & $0 \mathrm{E}-7$ \\
& Std. Deviation & 1,34899935 \\
Most Extreme & Absolute &, 076 \\
Differences & Positive &, 076 \\
& Negative &,- 066 \\
Kolmogorov-Smirnov Z & &, 766 \\
Asymp. Sig. (2-tailed) &, 600 \\
\hline a. Test distribution is Normal. & \\
b. Calculated from data. & \\
\multicolumn{2}{c}{ Sumber: Pengolahan data SPSS 20 }
\end{tabular}

Berdasarkan hasil uji One-Sample Kolmogorov-Smirnov Test nilai signifikansi atau dapat dilihat pada Asymp. Sig (2-tailed) sebesar 0,600 yang menunjukkan bahwa nilai signifikansi $>0,05$. Sehingga dapat disimpulkan bahwa data berdistribusi normal.

2) Uji multikolinieritas

Uji mulitikolinieritas yang digunakan dalam penelitian ini adalah dengan melihat nilai Variance Inflation Factor (VIF) dan nilai Tolerance. Berikut ini adalah hasil uji mulitikolinieritas dalam penelitian ini:

Tabel 4. Hasil Uji Multikolinieritas

\begin{tabular}{|c|c|c|c|c|c|c|c|}
\hline \multirow[t]{2}{*}{ Model } & \multicolumn{2}{|c|}{$\begin{array}{c}\text { Unstandardized } \\
\text { Coefficients }\end{array}$} & \multirow{2}{*}{$\begin{array}{l}\text { Standardized } \\
\text { Coefficients } \\
\text { Beta }\end{array}$} & \multirow[t]{2}{*}{$t$} & \multirow[t]{2}{*}{ Sig. } & \multicolumn{2}{|c|}{ Collinearity Statistics } \\
\hline & $\mathrm{B}$ & $\begin{array}{l}\text { Std. } \\
\text { Error }\end{array}$ & & & & Tolerance & VIF \\
\hline 1 (Constant) & 11,813 & 5,824 & & 2,028 & ,045 & & \\
\hline $\mathrm{OCl}$ &,- 901 & ,973 &,- 077 &,- 926 & ,357 & 1,000 & 1,000 \\
\hline $\mathrm{KAd}$ & 1,846 & ,271 &, 563 & 6,809 &, 000 & 1,000 & 1,000 \\
\hline
\end{tabular}

Berdasarkan tabel diatas, dapat dilihat bahwa nilai tolerance untuk masingmasing variabel memiliki nilai lebih dari 0,1, yaitu sebesar 1,000 dan nilai VIF kurang dari 10 yaitu sebesar 1,000. Sehingga dapat disimpulkan bahwa semua variabel independen yang digunakan dalam penelitian ini tidak terdapat korelasi antara satu variabel dengan variabel lainnya.

3) Uji heteroskedastisitas

Uji heteroskedastisitas yang digunakan dalam penelitian ini adalah dengan uji glejser. Berikut ini adalah hasil uji heteroskedastisitas dalam penelitian ini: 


\begin{tabular}{lccccc}
\hline Model & \multicolumn{2}{c}{$\begin{array}{c}\text { Unstandardized } \\
\text { Coefficients }\end{array}$} & $\begin{array}{c}\text { Standardized } \\
\text { Coefficients }\end{array}$ & $\mathrm{t}$ & Sig. \\
\hline \multicolumn{7}{c}{ B } & $\begin{array}{c}\text { Std. } \\
\text { Error }\end{array}$ & Beta & & \\
\hline 1 (Constant) & 3,289 & 3,104 & & 1,060 &, 292 \\
OCl &,- 383 &, 519 &,- 073 &,- 738 &, 462 \\
KAd &, 281 &, 145 &, 191 & 1,941 &, 055 \\
\hline a. Dependent Variable: ABS_RES1 & Sumber: Pengolahan data SPSS 20 &
\end{tabular}

Berdasarkan hasil uji heteroskedastisitas diatas, terlihat bahwa bahwa nilai Sig. untuk variabel pengungkapan other comprehensive income (OCI) dan kualitas audit (KAd) lebih dari 0,05. Sehingga dapat disimpulkan bahwa terdapat kesamaan varian residual dan tidak terjadi heteroskedastisitas.

4) Uji autokorelasi

Uji autokorelasi yang dilakukan dalam penelitian ini adalah dengan Metode Lagrange Multiplier (LM Test). Berikut ini adalah hasil dari uji atuokorelasi dalam penelitian ini:

Tabel 6. Hasil Uji Autokorelasi

\begin{tabular}{lcccc}
\hline Model & $\mathrm{R}$ & $\mathrm{R}$ Square & $\begin{array}{c}\text { Adjusted R } \\
\text { Square }\end{array}$ & $\begin{array}{r}\text { Std. Error of } \\
\text { the Estimate }\end{array}$ \\
\hline 1 &, $652^{\mathrm{a}}$ &, 425 &, 407 & 1,04302947 \\
\hline a. Predictors: (Constant), LAG_RES1, KAd, OCl & \\
b. Dependent Variable: Unstandardized Residual \\
Sumber : Pengolahan data dengan SPSS 20
\end{tabular}

Berdasarkan hasil uji autokorelasi diatas, didapat nilai $R$ Square sebesar 0,425 dengan jumlah sampel sebanyak 102 dan $n-1=101$, maka $X^{2}$ hitung sebesar 42,925 (101 x 0,425). Sedangkan nilai $X^{2}$ tabel dengan 101 (n-1) bernilai 125,458 . Karena nilai $X^{2}$ hitung $(42,925)<X^{2}$ tabel $(125,458)$, maka model persamaan regresi tidak mengandung masalah autokorelasi.

\section{Analisis regresi linier berganda}

Berdasarkan hasil uji regresi linier berganda, diperoleh hasil sebagai berikut :

Tabel 7. Hasil Uji Regresi Linier Berganda

\begin{tabular}{|c|c|c|c|c|c|}
\hline \multirow[t]{2}{*}{ Model } & \multicolumn{2}{|c|}{$\begin{array}{c}\text { Unstandardized } \\
\text { Coefficients }\end{array}$} & \multirow{2}{*}{$\begin{array}{c}\begin{array}{c}\text { Standardized } \\
\text { Coefficients }\end{array} \\
\text { Beta }\end{array}$} & \multirow[t]{2}{*}{$t$} & \multirow[t]{2}{*}{ Sig. } \\
\hline & $B$ & $\begin{array}{l}\text { Std. } \\
\text { Error }\end{array}$ & & & \\
\hline (Constant) & 11,813 & 5,824 & & 2,028 & , 045 \\
\hline $\mathrm{OCl}$ &,- 901 & ,973 &,- 077 &,- 926 & ,357 \\
\hline KAd & 1,846 & ,271 &, 563 & 6,809 &, 000 \\
\hline
\end{tabular}

a. Dependent Variable: PRICE

Sumber: Pengolahan data dengan SPSS 20

\section{Hasil uji hipotesis}


1) Hasil koefisien determinasi $\left(R^{2}\right)$

Berikut ini adalah hasil uji koefisien determinasi dalam penelitian ini:

Tabel 8. Hasil Uji Koefisien Determinasi

\begin{tabular}{lcccc}
\hline Model & $\mathrm{R}$ & $\mathrm{R}$ Square & $\begin{array}{c}\text { Adjusted R } \\
\text { Square }\end{array}$ & $\begin{array}{c}\text { Std. Error of } \\
\text { the Estimate }\end{array}$ \\
\hline $1 \quad, 569^{a}$ &, 324 &, 310 & 1,3625575 \\
\hline $\begin{array}{l}\text { a. Predictors: (Constant), KAd, OCl } \\
\text { b. Dependent Variable: PRICE } \\
\text { Sumber: Pengolahan data dengan SPSS } 20\end{array}$
\end{tabular}

Berdasarkan hasil uji koefisien determinasi diatas terlihat bahwa Adjusted $R$ Square untuk pengujian hipotesis pertama memiliki nilai 0,310 . Hal ini berarti bahwa 31\% variasi variabel relevansi nilai informasi akuntansi (PRICE) dapat dijelaskan oleh kedua variabel independen yaitu pengungakapan other comprehensive income (OCI) dan kualitas audit (KAd). Sedangkan sisanya $(100 \%-31 \%=69 \%)$ dijelaskan sebab-sebab lain diluar model.

2) Hasil uji statistik $F$

Berikut ini adalah hasil uji statistik $\mathrm{F}$ dalam penelitian ini:

Tabel 9. Hasil Uji Statistik F

\begin{tabular}{lccccc}
\multicolumn{7}{c}{ ANOVA $^{\mathrm{a}}$} \\
\hline Model & $\begin{array}{c}\text { Sum of } \\
\text { Squares }\end{array}$ & $\mathrm{df}$ & $\begin{array}{c}\text { Mean } \\
\text { Square }\end{array}$ & $\mathrm{F}$ & Sig. \\
\hline $1 \quad$ Regression & 87,999 & 2 & 44,000 & 23,699 &, $000^{\mathrm{b}}$ \\
& 183,800 & 99 & 1,857 & & \\
$\quad$ Residual & 271,799 & 101 & & & \\
$\quad$ Total & Sumber: Pengolahan data dengan SPSS 20 & \\
\hline a. Dependent Variable: PRICE &
\end{tabular}

Berdasarkan hasil uji statistik F diatas, terlihat bahwa nilai F sebesar 23,699 dengan nilai Sig. kurang dari 0,05 yaitu sebesar 0,000. Hal ini menunjukkan bahwa model regresi yang digunakan fit dan dapat dikatakan bahwa variabel independen secara keseluruhan berpengaruh terhadap variabel dependen (PRICE).

3) Hasil uji statistik t

Berikut ini adalah hasil uji statistik t untuk hipotesis pertama dalam penelitian ini:

Tabel 10. Hasil Uji Statistik t

\begin{tabular}{|c|c|c|c|c|}
\hline \multicolumn{5}{|c|}{ Coefficientsa } \\
\hline Model & $\begin{array}{l}\text { Unstandardized } \\
\text { Coefficients }\end{array}$ & $\begin{array}{l}\text { Standardized } \\
\text { Coefficients }\end{array}$ & $t$ & Sig. \\
\hline & $\begin{array}{lc}\text { B } & \text { Std. } \\
& \text { Error }\end{array}$ & Beta & & \\
\hline
\end{tabular}




\begin{tabular}{ccccccc}
\hline 1 & (Constant) & 11,813 & 5,824 & 2,028 &, 045 \\
& $\mathrm{OCl}$ &,- 901 &, 973 &,- 077 &,- 926 &, 357 \\
& $\mathrm{KAd}$ & 1,846 &, 271 &, 563 & 6,809 &, 000 \\
\hline \multicolumn{7}{c}{ a. Dependent Variable: PRICE } \\
\multicolumn{7}{c}{ Sumber: Pengolahan data dengan SPSS 20 }
\end{tabular}

Berdasarkan hasil uji statistik $\mathrm{t}$ diatas, terlihat bahwa nilai $\mathrm{t}$ untuk variabel OCI sebesar $-0,926$ dengan tingkat signifikansi sebesar 0,357. Tingkat signifikansi tersebut bernilai lebih besar dari $\alpha=0,05$ yang berarti bahwa pengungkapan OCI tidak berpengaruh terhadap relevansi nilai informasi akuntansi secara parsial.

Untuk variabel moderator yaitu kualitas audit (KAd) menunjukkan tingkat signifikansi sebesar 0,000 yang berarti lebih kecil dari $\alpha=0,05$. Sehingga dapat disimpulkan bahwa kualitas audit berpengaruh terhadap relevansi nilai informasi akuntansi secara parsial.

\section{Uji moderasi variabel dummy (sub-group)}

Kualitas audit sebagai variabel moderator dibagai menjadi 2 group, yaitu KAP big four dan KAP non big four. Berdasarkan analisis ini, dibentuk 3 model regresi berikut ini :

\section{Model Regresi 1:}

PRICE $=\alpha 1+\alpha 2$ OCI $+\varepsilon 1$ untuk total sampel KAP big four dan non big four

\section{Model Regresi 2:}

PRICE $=\beta 1+\beta 2$ OCI $+\varepsilon 2$ untuk total sampel KAP big four

\section{Model Regresi 3:}

PRICE $=\lambda 1+\lambda 2$ OCI $+\varepsilon 3$ untuk total sampel KAP non big four

Berikut ini hasil output tabel ANOVA SPSS ketiga persamaan regresi diatas :

Tabel 11. ANOVA model regresi 1

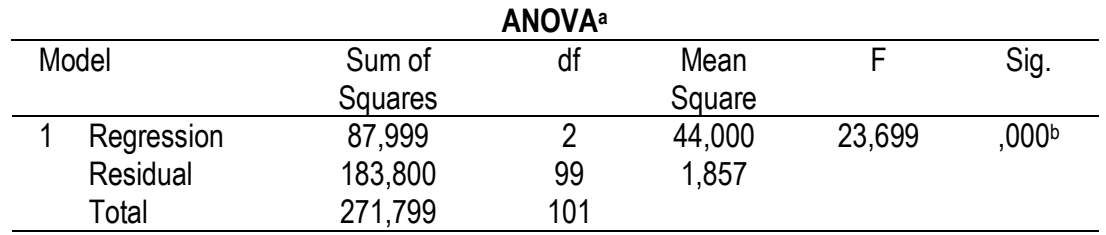

a. Dependent Variable: PRICE

b. Predictors: (Constant), KAd, OCl

Sumber: Pengolahan data dengan SPSS 20

Tabel 12. ANOVA model regresi 2

\begin{tabular}{|c|c|c|c|c|c|}
\hline \multicolumn{6}{|c|}{ ANOVAa $^{a}$} \\
\hline Model & $\begin{array}{l}\text { Sum of } \\
\text { Squares }\end{array}$ & $d f$ & $\begin{array}{l}\text { Mean } \\
\text { Square }\end{array}$ & $F$ & Sig. \\
\hline $\begin{array}{ll}1 & \text { Regression } \\
& \text { Residual }\end{array}$ & $\begin{array}{c}5,871 \\
110,127\end{array}$ & $\begin{array}{c}1 \\
44\end{array}$ & $\begin{array}{l}5,871 \\
2,503\end{array}$ & 2,346 &, $133^{b}$ \\
\hline
\end{tabular}




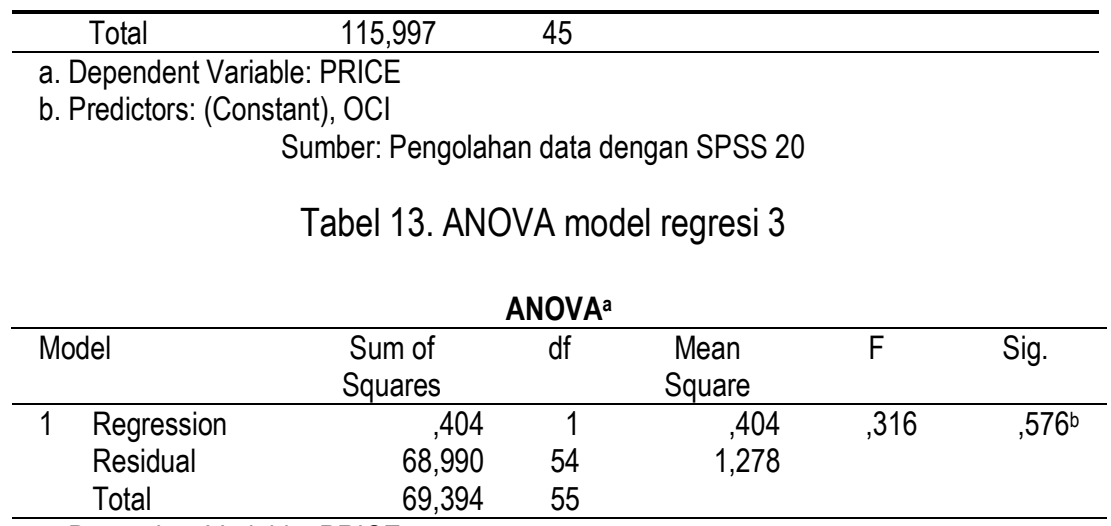

a. Dependent Variable: PRICE

b. Predictors: (Constant), $\mathrm{OCl}$

Sumber: Pengolahan data dengan SPSS 20

Berdasarkan tabel ANOVA untuk model regresi 1, 2 dan 3, diperoleh nilai restricted residual sum of squares atau RSSr sebagai berikut :

1. Nilai RSSr (RSS3) untuk total sampel KAP big four dan KAP non big four sebesar 183,800

2. Nilai RSSr (RSS1) untuk total sampel KAP big four sebesar 110,127

3. Nilai RSSr (RSS2) untuk total sampel KAP non big four sebesar 68,990

4. Nilai RSSur (RSS1 + RSS2) sebesar 179,117

Dengan menggunakan rumus uji Chow, diperoleh hasil sebagai berikut :

$$
\begin{aligned}
\text { F hitung } & =\frac{(\text { RSS3 }- \text { RSSur }) / \mathrm{k}}{(\text { RSSur }) /(\mathrm{n} 1+\mathrm{n} 2-2 \mathrm{k})} \\
& =\frac{(183,800-179,117) / 2}{(179,117) /(46+56-4)} \\
=1,28 &
\end{aligned}
$$

Berdasarkan hasil $\mathrm{F}$ hitung yang diperoleh sebesar 1,28 dan $\mathrm{F}$ tabel $(\mathrm{df} 1=2$, df2=98) sebesar 3,09. Dikarenakan $\mathrm{F}$ hitung $<\mathrm{F}$ tabel, maka $\mathrm{H}_{1}$ ditolak, dan dapat disimpulkan bahwa kualitas audit tidak memoderasi pengaruh pengungkapan OCI terhadap relevansi nilai informasi akuntansi.

\section{Analisis hasil penelitian}

Hasil penelitian menunjukkan bahwa pengungkapan other comprehensive income tidak berpengaruh terhadap relevansi nilai informasi akuntansi yang dimoderasi dengan kualitas audit. Berdasarkan teori yang digunakan dalam penelitian ini, yaitu teori sinyal, suatu perusahaan seharusnya memberikan sinyal yang berguna bagi para pengguna laporan keuangan. Sinyal yang diberikan dapat berupa informasi yang ada di dalam laporan keuangan terkait bagaimana upaya manajemen perusahaan dalam mengelola perusahaan untuk mendapatkan keuntungan semaksimal mungkin maupun bagaimana mempertahankan kelangsungan perusahaan. Apabila informasi terkait OCI dianggap penting dan berguna maka pengguna laporan keuangan terutama investor akan menganggap informasi OCI tersebut sebagai sebuah sinyal dan digunakan sebagai bahan pertimbangan pengambilan keputusan sehingga akan mempengaruhi harga saham perusahaan. 
Namun, berdasarkan pengujian yang telah dilakukan, hipotesis dalam penelitian ini tidak dapat dibuktikan. Penyebabnya dapat diakibatkan karena investor di Indonesia yang sebagian besar tidak menggunakan kualitas informasi yang ada dalam laporan keuangan ketika melakukan transaksi di pasar modal. Faktor kerumitan dalam menganalisis informasi akuntansi merupakan salah satu penyebab utamanya. Sehingga meskipun informasi akuntansi telah melalui proses audit yang berkualitas, hal tersebut tetap tidak mempengaruhi keputusan investor dalam berinvestasi (Apandi, 2015).

Selain ini, hasil penelitian tersebut menunjukkan bahwa para investor di Indonesia belum terlalu memahami bahwa informasi OCI yang dilaporkan dalam laporan keuangan, yaitu laporan laba rugi dan komprehensif lain menunjukkan informasi yang relevan karena penggunaan asumsi, estimasi dan judgement oleh manajemen perusahaan. Hasil penelitian ini sejalan dengan hasil penelitian Apandi (2015) yang juga menemukan bahwa pengungkapan OCI tidak berpengaruh terhadap relevansi nilai informasi akuntansi yang diperkuat dengan kualitas audit. Akan tetapi hasil penelitian ini tidak sejalan dengan hasil penelitian Lee dan Park (2013) dan Pranita (2016) yang menemukan bahwa pengungkapan OCI yang diperkuat dengan kualitas audit berpengaruh terhadap relevansi nilai informasi akuntansi.

\section{Kesimpulan dan Saran}

Berdasarkan hasil analisis data, pengujian, dan pembahasan, maka dapat disimpulkan bahwa hasil pengujian hipotesis menunjukkan pengungkapan OCI tidak berpengaruh terhadap relevansi nilai informasi akuntansi yang dimoderasi oleh kualitas audit.

Berdasarkan hasil penelitian yang telah dijelaskan, maka penulis memberikan saran bagi peneliti selanjutnya:

1. Penelitian selanjutnya diharapkan dapat menggunakan sampel berupa perusahaan dengan sektor industri yang lebih beragam.

2. Penelitian selanjutnya diharapkan dapat menambah variabel independen yang dapat mempengaruhi relevansi nilai informasi akuntansi, seperti net income, cash flow, book value of equity, dan lainnya.

\section{Referensi}

Ahalik. (2015). Panduan Praktis PSAK Terkini Berbasis IFRS Terkait OCI vs SAK ETAP. Edisi 2. Ikatan Akuntan Indonesia, Jakarta.

Apandi, R. N. N. (2015). Relevansi Nilai, Subjektifitas Other Comprehensive Income dan Kualitas Audit. Simposium Nasional Akuntansi 18, 16-19 September. Medan: Universitas Sumatera Utara

Aprilianto, B., Novi ,W., dan Taufik, K., (2014). Perilaku investor saham individual dalam pengambilan keputusan investasi: Studi Hermeneutika-Kritis. EJournal Ekonomi Bisnis dan Akuntansi. Vol. 1 No.1.

Arens, A. A., Randal, J. E., dan Mark, B. (2012). Auditing and Assurance Service: an Integrated Approach. Pearson Education Inc, New Jersey. 
Ariyadi, F., Adi W., dan Darmansyah. (2018). Relevansi Nilai dan Subjektifitas dari Other Comprehensive Income pada Perusahaan Industri Jasa Keuangan. JIPI. Vol. 2 No. 1.

Aryati, Titik., dan Natasya Nadia Wibowo. (2017). Pengaruh Relevansi Nilai Informasi Other Comprehensive Income dan Net Income Terhadap Return Saham. Jurnal Riset Akuntansi, Auditing \& Informasi. Vol. 17 No. 1.

Ayu., dan Siregar. (2014). The Effect of IFRS Convergence on Value Relevance of Accounting Information: Cross-Country Analysis of Indonesia, Malaysia and Singapore. Simposium Nasional Akuntansi 17. 24-27 September 2014. Nusa Tenggara Barat: Universitas Mataram.

Brigham, E. F., dan Houston, J. F. (2011). Dasar-dasar Manajemen Keuangan. Edisi 11. Salemba Empat, Jakarta.

Cahyonowati, N., dan Ratmono, D. (2012). Adopsi IFRS dan Relevansi Nilai Informasi Akuntansi. Jurnal Akuntansi dan Keuangan, Vol. 14, No. 2.

Connelly, B. L., dkk. (2011). Signalling Theory: a Review and Assesment. Journal of Management. Vol. 37 No. 1.

Fahmi, I. (2012). Analisis Laporan Keuangan. Cetakan Ke-2. Alfabeta, Bandung.

Ghozali, I. (2013). Aplikasi Analisis Multivariate Dengan Program IBM SPSS 21. Edisi 7. Badan Penerbit UNDIP, Semarang.

Ikatan Akuntan Indonesia. (2013). Standar Akuntansi Keuangan. Jakarta: Salemba Empat.

Indonesia. Peraturan Tentang Kewajiban Emiten Menyampikan Laporan Keuangan Berkala. Keputusan Ketua Badan Pengawas Pasar Modal (BAPEPAM), Nomor: Kep-36/PM/2003.

Indonesia. Undang-Undang Ketenagakerjaan. Undang-Undang No.13 Tahun 2013.

Jogiyanto. H. M. (2010). Teori Portofolio dan Analisis Investasi. Edisi Ketiga. BPFE, Yogyakarta.

Lee, C., dan Park, M. S. (2013). Subjectivity in Fair-value Estimates, Audit Quality, and Informativeness of Other Comprehensive Income. Advances in Accounting, Incorporating Advances in International Accounting.

Mayangsari, S. (2004). Analisa Relevansi Nilai (value-relevance, Laba, Arus kas, dan Nilai Buku Ekuitas: Analisis Diseputar Periode Krisis Keuangan 1995-1998. Simposium Nasional Akuntansi 7, 2-3 Desember 2004. Denpasar: Universitas Udayana. 
Naimah, Z. (2014). Relevansi Nilai Informasi Akuntansi: Suatu Kajian Teoritis. Jurnal Buletin Studi Ekonomi. Vol.19, No.1.

Pranita, I. (2016). Pengaruh Kualitas Audit Terhadap Hubungan Pengungkapan Other Comprehensive Income dengan Relevansi Nilai Informasi Akuntansi pada Perusahaan yang Terdaftar di Bursa Efek Indonesia. Tesis. Padang

Pratiwi, E., Rini I., dan Pratana., P. M. (2012). Relevansi Nilai Informasi Laporan Keuangan dan Komponen Laba Rugi Komprehensif dalam Menjelaskan Harga dan Return Saham. Bandung: Lembaga Penerbitan Laboratorium Akuntansi UPI.

Puspitaningtyas, Z. (2012). Relevansi Nilai Informasi Akuntansi dan Manfaatnya bagi Investor. Ekuitas: Jurnal Ekonomi dan Keuangan. No. 110/DIKTI/Kep/200

Sinarto, R. J., dan Christiawan, J. J. (2014). Pengaruh Penerapan IFRS terhadap Relevansi Nilai Laba Laporan Keuangan. Tax \& Accounting Review. Vol. 4, No. 1

Simamora, N. S. "Saham-Saham Konsumer Kian Diminati Investor". www.google.co.id/amp/m.bisnis/amp/read/20170303/190/633538//saha m-saham-konsumer-kian-diminati-investor. (Diakses pada tanggal 12 September 2018, 16.10 WIB)

Suwardjono. (2008). Teori Akuntansi: Perekayasaan Pelaporan Keuangan. BPFE, Yogyakarta.

Wahyu, R. P. S., dan Praptoyo, S. (2014). Penyajian dan Komponen Other Comprehensive Income. Jurnal Ilmu \& Riset Akuntansi. Vol.3 No.12.

Widiastuty, E., dan Febrianto, R. (2010). Pengukuran Kualitas Audit: Sebuah Esai. Jurnal Ilmiah Akuntansi dan Bisnis. Vol.5 No.2.

Yudiman, A. T., Darmansyah., dan Nurmala A. (2017). Relevansi Nilai Net Income dan Other Comprehensive Income pada Perusahaan Manufaktur. JIPI. Vol.1 No.1. 